\title{
Insecticidal toxicities of essential oils extracted seven plants against Ricania sp. nymphs and adults
}

\author{
Ye-Jin Jeon ${ }^{1} \cdot$ Byeong-Ryeol Choi ${ }^{2} \cdot$ Hoi-Seon Lee $^{1}$

\section{돌발 해충, 갈색날개매미충에 대한 7종 식물체 오일성분의 살충효과}

전예진 ${ }^{1} \cdot$ 최병렬 ${ }^{2} \cdot$ 이회선 ${ }^{1}$

Received: 4 June 2016 / Accepted: 7 June 2016 / Published Online: 30 September 2016

(C) The Korean Society for Applied Biological Chemistry 2016

\begin{abstract}
The insecticidal toxicities of seven essential oils against Ricania sp. nymph and adults, newly recorded pest, were evaluated using leaf-dipping and spray methods. At $72 \mathrm{~h}$ exposure time, the $\mathrm{LC}_{50}$ values of the essential oils of Artemisia vulgaris, Anethum graveolens, Citrus paradisi, Melaleuca alternifolia, Melaleuca leucadendron, Neroli bigarade and Tagetes erecta were 251.02, 387.31, 286.21, 353.54, 275.64, 424.55, $165.68 \mathrm{mg} /$ $\mathrm{cm}^{2}$ when using the leaf dipping method against Ricania sp. nymphs, and 278.31, 402.11, 306.11, 379.64, 298.22, 459.56, $183.21 \mathrm{mg} / \mathrm{cm}^{2}$ when using the spray method against Ricania $\mathrm{sp}$. adults, respectively. These results indicate that the essential oil of the Tagetes erecta can be potentially used as new natural insecticidal agents against Ricania sp. nymph and adults.
\end{abstract}

Keywords Essential oil · Insecticidal toxicities · Newly recorded pest $\cdot$ Ricania sp. $\cdot$ Tagetes erecta

Hoi-Seon Lee $(\bowtie)$

E-mail: hoiseon@jbnu.ac.kr

${ }^{1}$ Department of Bioenvironmental Chemistry and Institute of Agricultural Science \& Technology, College of Agriculture \& Life Science, Chonbuk National University, Jeonju 54896, Republic of Korea

${ }^{2}$ Crop Protection Division, National Academy of Agriculture Science, Rural Development Administration, Wanju 55365, Republic of Korea

This is an Open Access article distributed under the terms of the Creative Commons Attribution Non-Commercial License (http://creativecommons. org/licenses/by-nc/3.0/) which permits unrestricted non-commercial use, distribution, and reproduction in any medium, provided the original work is properly cited.

\section{서 론}

갈색날개매미충(Ricania sp.)은 큰날개매미충(Ricaniidae)에 속하 는 돌발해충으로 주로 중국 저지앙 지역에서 사과, 복숭아, 감, 블루베리 등을 포함한 다양한 과수에 엄청난 손상을 가하는 새 로운 해충으로 보고되었다 $(\mathrm{Xu}$ 등, 2006; Shen 등, 2007; Rahman 등, 2012). 우리나라에는 갈색날개매미충이 2010년 충 청남도에서 처음 발견되었다(Choi 등, 2011; Choi 등, 2012). 갈색날개매미충은 발견 초기에는 외국으로부터 들어온 외래해 충 및 돌발해충으로 보고되었으나, 확인이 되지 않은 종으로 의 견이 모아지고 있으며, 알부터 성충까지의 모든 생애 사이클이 산 등에서 보내는 종이였으나, 식생과 기후 등의 변화로 인하 여 짧은시간 내 급작스럽게 개체수의 증가하여 작물에 큰 피해 를 입히고 있다(Choi 등, 2011; Choi 등, 2012). 갈색날개매미 충은 알에서 부화해 5 회 가량 탈피하고 난 후 성충으로 되며, 약충의 경우 항문을 중심으로 백색, 황색의 왁스질 밀납을 가 지고 있다(Choi 등, 2011). 약충은 날아다니지는 않지만 도약지 로 점프하여 멀리 이동이 가능하며 항문에 있는 왁스질 밀납 형상물이 점프하는 데에 사용되고 있다. 성충은 수컷의 경우 $8.26 \mathrm{~mm}$ 와 암컷은 $8.77 \mathrm{~mm}$ 으로 암컷이 조금 크고, 수컷의 복 부는 뾰족한 반면 암컷은 둥글어 암수구별이 가능하다(Choi 등, 2012). 성충과 약충은 기주 식물에서 군집생활하며, 성충의 경 우 유백색의 가지 속에 긴 타원형 알을 산란한다. 산란 후 흰 색의 왁스질 밀납이 난괴 위에 덮히며, 밀납으로 보호하는 산 란의 습성은 알로 월동하는 갈색날개매미충의 난괴 부화율을 높 이고 주변의 천적으로부터 알을 보호할 수 있는 장점을 제공한 다(Choi 등, 2011). 그럼에도 불구하고 갈색날개매미충은 일반 적으로 외형이 유사한 종의 생식 특성을 통하여 식별하려는 국 내과학자들의 노력에도 불구하고 현재까지 종 동정이 확인되지 않고 있는 실정이다(Rahman 등, 2012). 이러한 이유로 국내에 서 급속도로 퍼져가고 있는 갈색날개매미충에 대한 살충제 개 
발이 시급함에도 불구하고 현실적인 방제 방법이 없어서 어려 움을 겪고 있다.

식물체로부터 연속증류추출법을 이용하여 추출된 정유성분은 방향성 물질 및 대사 물질이며(Hyun 등, 2015; Kim 등, 2015), 이러한 정유성분으로부터 유래된 방향성 소재는 여러 해충에 대 한 생장조절제, 살란제, 살비제 및 살충제의 중요한 천연자원으 로서 친환경 살충제로서 개발 잠재성을 가지고 있다(Gbolade 등, 2000; Isman 2000, Lee과 Lee 2015). 본 연구에서는 갈색 날개매미충 약충 및 성충에 대하여 쑥(Artemisia vulgaris), 딜 (Anethum grav eolens), 자몽(Citrus paradisi), 티트리(Melaleuca alternifolia), 카제풋(Melaleuca leucadendron), 네롤리(Neroli bigarade) 및 만수국(Tagetes erecta)에서 추출한 정유성분을 이용 하여 생물검정을 실시하여 살충 효과를 비교분석하였다.

\section{재료 및 방법}

\section{식물 추출방법 및 해충 채집}

본 연구에 사용된 7종 식물체의 잎, 종자 및 꽃을 전주 소재 한약재 판매점 및 화훼농장에서 구입하여 실험에 사용하였다. 식물체에 대한 검증은 전북대학교 농생대 조경과 김정문교수 연 구팀에 의하여 검증되었다. 7종 식물체는 연속증류추출법 (Simultaneous Distillation Extraction)을 이용하여 추출을 진행하 였으며, 순수한 정유 성분을 얻기 위해 추출 후에 존재하는 수 분을 황산나트륨 $\left(\mathrm{Na}_{2} \mathrm{SO}_{4}\right)$ 으로 완전히 제거하였다. 이들 식물체 의 각각의 학명 및 수율은 Table 1 에 나타내었다. 갈색날개매 미충 약충 및 성충은 완주군 감나무에서 채집하였다.

\section{생물검정법}

본 연구에서는 한국응용곤충학회 및 미국곤충학회의 지침에 따 른 엽침지법 및 직접분무법을 이용하였으며, 모든 실험규정은 국립농업과학원에 의해 승인된 방법을 사용하였다. 갈색날개매 미충 약충에 대한 살충활성 측정은 7종 식물체 정유성분으로 엽침지법을 사용하였으며, Cuthbertson 등(2009)이 제안한 절차 에 따라 살충활성을 평가하였다. 정유성분은 증류수와 계면활성 제(Triton X-100)을 혼합한 현탁액을 이용하여 다양한 농도 $(1,000-50 \mathrm{mg} / \mathrm{L})$ 로 희석하여 용해시킨 후에 무궁화 잎에 6 분 동 안 적시고 건조시켜 밀폐된 용기 $(65 \times 20 \mathrm{~cm})$ 에 약충을 처리하였 다. 처리된 용기는 온도 $21 \pm 2^{\circ} \mathrm{C}$ 과 광주기 $12 \mathrm{~L}: 12 \mathrm{D}$ 의 조건하에 서 72 시간 동안 살충여부를 확인하였다. 대조구로 증류수와 계 면활성제(Triton X-100)을 혼합한 현탁액을 사용하였으며, 모든 처리는 3 반복으로 진행하였다. 갈색날개매미충 성충은 Choi 등 (2012)의 실험을 응용한 직접분무법을 이용하여 각 시료의 살 충활성을 검증하였다. 갈색날개매미충 성충 30 개체씩 접종하 고 각 정유성분을 증류수와 계면활성제(Triton X-100)을 혼합한 현탁액을 이용하여 다양한 농도 $(1,000-50 \mathrm{mg} / \mathrm{L})$ 로 녹인 시료는 상자 $(10 \times 5 \times 5 \mathrm{~cm})$ 에 분무한 후, 마개를 닫고 밀봉하여 온도 $21 \pm$ $2^{\circ} \mathrm{C}$ 과 광주기 $12 \mathrm{~L}: 12 \mathrm{D}$ 의 조건하에서 72 시간 동안 유지하였다.

\section{통계분석}

모든 실험은 3 반복으로 진행하였으며, 붓으로 갈색날개매미충을 자극하여도 움직이지 않는 개체를 죽은 것으로 간주하여 살충
여부를 확인하였고, 갈색날개매미충에 대한 반수치사농도(Lethal concentration $50, \mathrm{LC}_{50}$ )는 Probit 분석으로 측청하였다.

\section{결과 및 고찰}

본 연구에서는 쑥(A. vulgaris) 잎, 딜(A. graveolens) 종자, 자 몽(C. paradisi) 껍질, 티트리(M. alternifolia) 잎, 카제풋 $(M$. leucadendron) 잎, 네롤리(N. bigarade) 꽃 및 만수국(T. erecta) 꽃을 연속증류추출법으로 정유성분을 추출하였고, 7종 식물체 정유성분 수율은 각각 $0.186,3.865,0.537,0.998,1.732,0.954$ 및 $1.455 \%$ 으로 확인되었다(Table 1). 갈색날개매미충(Ricania sp.) 유충 및 성충은 엽침지법과 직접분무법을 이용하여 48시간 과 72시간 처리시킨 후에 7종 식물체 정유성분의 살충활성을 검증하였다(Table 2). 갈색날개매미충 유충을 엽침지법을 이용 하여 48시간 처리하였을 때에 7종 정유성분의 반수치사농도는 각각 쑥 $300.02 \mathrm{mg} / \mathrm{cm}^{2}$, 딜 $445.12 \mathrm{mg} / \mathrm{cm}^{2}$, 자몽 $325.03 \mathrm{mg} / \mathrm{cm}^{2}$, 티트리 $425.65 \mathrm{mg} / \mathrm{cm}^{2}$, 카제풋 $316.35 \mathrm{mg} / \mathrm{cm}^{2}$, 네롤리 512.23 $\mathrm{mg} / \mathrm{cm}^{2}$, 만수국 $206.22 \mathrm{mg} / \mathrm{cm}^{2}$ 이며, 72시간 처리하였을 때에 반 수치사농도는 쑥 $251.02 \mathrm{mg} / \mathrm{cm}^{2}$, 딜 $387.31 \mathrm{mg} / \mathrm{cm}^{2}$, 자몽 $286.21 \mathrm{mg} / \mathrm{cm}^{2}$, 티트리 $353.54 \mathrm{mg} / \mathrm{cm}^{2}$, 카제풋 $275.64 \mathrm{mg} / \mathrm{cm}^{2}$, 네롤리 $424.55 \mathrm{mg} / \mathrm{cm}^{2}$, 만수국 $165.68 \mathrm{mg} / \mathrm{cm}^{2}$ 이었다. 갈색날개 매미충 성충에 대한 직접분무법을 이용한 반수치사농도는 48 시 간 처리하였을 때에 각각 쑥 $316.22 \mathrm{mg} / \mathrm{cm}^{2}$, 딜 $469.92 \mathrm{mg} / \mathrm{cm}^{2}$, 자몽 $356.11 \mathrm{mg} / \mathrm{cm}^{2}$, 티트리 $452.14 \mathrm{mg} / \mathrm{cm}^{2}$, 카제풋 339.77 $\mathrm{mg} / \mathrm{cm}^{2}$, 네롤리 $528.33 \mathrm{mg} / \mathrm{cm}^{2}$, 만수국 $218.32 \mathrm{mg} / \mathrm{cm}^{2}$ 이며, 72 시간 처리하였을 때에 반수치사농도는 각각 쑥 $278.31 \mathrm{mg}$ $\mathrm{cm}^{2}$, 딜 $402.11 \mathrm{mg} / \mathrm{cm}^{2}$, 자몽 $306.11 \mathrm{mg} / \mathrm{cm}^{2}$, 티트리 379.64 $\mathrm{mg} / \mathrm{cm}^{2}$, 카제풋 $298.22 \mathrm{mg} / \mathrm{cm}^{2}$, 네롤리 $459.56 \mathrm{mg} / \mathrm{cm}^{2}$, 만수국 $183.21 \mathrm{mg} / \mathrm{cm}^{2}$ 으로 살충활성을 보였다. 7종 식물체 정유성분에 따른 갈색날개매미충 유충과 성충에 대한 반치수농도는 다양하 였으며, $\mathrm{LC}_{50}$ 은 48 시간에서 72 시간으로 지날수록 살충독성이 증 가하였다. 두 가지 생물살충검정법(엽침지법과 직접분무법)을 이 용한 갈색날개매미충 유충과 성충에 대한 반치수농도를 비교분 석 하였을 때에 만수국이 가장 높은 살충독성을 나타냈으며, 만 수국의 살충독성은 갈색날개매미충 유충이 성충에 비해 1.1 배 더 높은 살충효과를 나타내었다. 식물체 정유를 처리하지 않은 음성대조구는 살충효과가 나타나지 않았다. 본 연구에서 양성대 조구를 사용하지 않은 것은 갈색날개매미충이 처음 보고된 외 래해충으로 아직까지 보고된 살충제가 존재하지 않아서 양성대 조구를 사용할 수 없었다. 이전 연구에 따르면, 갈색날개매미충

Table 1 Yields of essential oils extracted the seven plants

\begin{tabular}{lccc}
\multicolumn{1}{c}{ Plant species } & Plant species & $\begin{array}{c}\text { Tissue } \\
\text { sampled }\end{array}$ & Yield (\%) \\
\hline Artemisia vulgaris & Compositae & leaf & 0.186 \\
Anethum graveolens & Apiaceae & seed & 3.865 \\
Citrus paradisi & Rutaceae & peel & 0.537 \\
Melaleuca alternifolia & Myrtaceae & leaf & 0.998 \\
Melaleuca leucadendron & Myrtaceae & leaf & 1.732 \\
Neroli bigarade & Rutaceae & flower & 0.954 \\
Tagetes erecta & Compositae & flower & 1.455 \\
\hline
\end{tabular}

${ }^{1)}$ Yield (\%) $=($ Dried weight of essential oil/dried weight of sample $) \times 100$ 
Table 2 Insecticidal toxicities of the seven plant oils against Ricania sp. nymphs and adults at 48 and $72 \mathrm{~h}$ exposure times ${ }^{1)}$

\begin{tabular}{lccc}
\hline \multirow{2}{*}{ Plant species } & \multirow{2}{*}{$\begin{array}{c}\text { Exposure } \\
\text { times (h) }\end{array}$} & \multicolumn{2}{c}{ Stage of insect development } \\
\cline { 3 - 4 } Artemisia vulgaris & 48 & $300.02 \pm 15.66$ & $316.22 \pm 21.37$ \\
& 72 & $251.02 \pm 17.09$ & $278.31 \pm 19.65$ \\
\hline \multirow{2}{*}{ Anethum graveolens } & 48 & $445.12 \pm 19.39$ & $469.92 \pm 22.36$ \\
& 72 & $387.31 \pm 16.88$ & $402.11 \pm 18.91$ \\
\hline \multirow{2}{*}{ Citrus paradisi } & 48 & $325.03 \pm 18.67$ & $356.11 \pm 18.99$ \\
& 72 & $286.21 \pm 18.89$ & $306.11 \pm 17.69$ \\
\hline \multirow{2}{*}{ Melaleuca alternifolia } & 48 & $425.65 \pm 19.36$ & $452.14 \pm 20.64$ \\
& 72 & $353.54 \pm 15.46$ & $379.64 \pm 20.11$ \\
\hline \multirow{2}{*}{ Melaleuca leucadendron } & 48 & $316.35 \pm 15.33$ & $339.77 \pm 18.52$ \\
& 72 & $275.64 \pm 19.36$ & $298.22 \pm 16.78$ \\
\hline \multirow{2}{*}{ Neroli bigarade } & 48 & $512.23 \pm 18.45$ & $528.33 \pm 20.45$ \\
& 72 & $424.55 \pm 12.43$ & $459.56 \pm 18.65$ \\
\hline \multirow{2}{*}{ Tagetes erecta } & 48 & $206.22 \pm 12.21$ & $218.32 \pm 15.24$ \\
& 72 & $165.68 \pm 10.34$ & $183.21 \pm 12.11$ \\
\hline \multirow{2}{*}{ Negative Control } & 48 & $-4)$ & - \\
& 72 & - & - \\
\hline
\end{tabular}

${ }^{1)}$ Each value is the average of 3 determinations, with 30 Ricania $\mathrm{sp}$ nymphs and adults per replication

${ }^{2)}$ Leaf dipping method: $\mathrm{LC}_{50}\left(\mathrm{mg} / \mathrm{cm}^{2}\right)$

${ }^{3}$ Spray method: $\mathrm{LC}_{50}\left(\mathrm{mg} / \mathrm{cm}^{2}\right)$

${ }^{4)}$ No activity

유충 및 성충에 대한 정유성분의 감수성 차이는 글투타치온 $\mathrm{S}$ 전달효소 및 가수분해효소를 해독하는 생물학적 요소와 유충 및 성충의 차이에 기인한다고 보고되었다(Lee과 Lee 2015).

천연물을 이용한 친환경 살충제에 대한 관심이 높아짐에 따 라 국내 갈색날개매미충을 대상으로 한 연구에 따르면, Lee 등 (2016)은 정향(Eugenia caryophyllata) 정유성분 및 유도체의 살 충활성을 보고하였으며, Choi 등(2012)은 고삼(Sophora flavescens) 추출물의 살충효과를 보여주었다. 본 연구에서 만수국을 비롯한 7 종 식물체 정유성분은 갈색날개매미충 유충 및 성충에 대해 살 충독성이 처음 보고되었으며, 외래 해충을 방제 가능한 천연 살 충제로 판단된다. 이러한 천연살충제는 합성살충제와 달리 갈색 날개매미충이 주로 서식하는 과수에 지속적인 사용으로 인해 발 생하는 잔류독성 우려가 없고 친환경적이며, 천연살충제에 관한 연구는 여전히 전세계적으로 수행되고 있다. 따라서 인축 독성 을 감소시키고 돌발해충 갈색날개매미충 유충 및 성충에 대해 살충활성을 향상시키는 연구가 수행되어야 하며, 추후 연구를 통해 친환경 소재 시장 및 상업화가 확대될 것으로 보여진다.

\section{초 록}

현재 급속하게 퍼져가고 있는 외래해충이면서 돌발해충인 갈색 날개매미충 유충 및 성충의 천연살충제를 개발하기 위하여 엽 침지법과 직접분무법을 이용하여 쑥(Artemisia vulgaris), 딜 (Anethum graveolens), 자몽(Citrus paradisi), 티트리(Melaleuca alternifolia), 카제풋(Melaleuca leucadendron), 네롤리(Neroli bigarade) 및 만수국(Tagetes erecta)에서 추출한 정유성분을 이 용하여 살충효과를 실험하였다. 갈색날개매미충 유충에 대한 살 충효과는 엽침지법을 이용하여 72시간에 7종 정유성분을 각각 처리하였을 때에 쑥, 딜, 자몽, 티트리, 카제풋, 네롤리 및 만수 국 정유성분 순서별로 반수치농도 $\left(\mathrm{LC}_{50}\right)$ 는 각각 $251.02,387.31$, $286.21,353.54,275.64,424.55,165.68 \mathrm{mg} / \mathrm{cm}^{2}$ 이며, 직접분무 법을 이용한 갈색날개매미충 성충의 반수치사농도는 각각 278.31, 402.11, 306.11, 379.64, 298.22, 459.56, $183.21 \mathrm{mg} / \mathrm{cm}^{2}$ 으로 살충활성을 보였다. 이러한 연구결과를 바탕으로 만수국의 정유가 갈색날개매미충 유충 및 성충에 대하여 친환경 살충제 로써 적용 가능성을 보여주며, 더 나아가 식물체 정유성분을 이 용한 외래해충 방제 기술을 응용한 제품의 다양화에 기여할 것 이다.

Keywords 갈색날개매미충·돌발해충·만수국·살충독성·정유성분

Acknowledgements This work was carried out with the support of "Cooperative Research Program for Agriculture Science \& Technology Development (Project title: Study on the ecology and development of management practice for an exotic and epidemic pest, Ricania sp., Project No. PJ0116902016)" Rural Development Administration, Republic of Korea.

\section{References}

Choi DS, Kim DI, Ko SJ, Kang BR, Lee KS, Park JD, Choi KJ (2012) Occurrence ecology of Ricania sp. (Hemiptera: Ricaniidae) and selection of environmental friendly agricultural materials for control. Kor J Appl Entomol 51: 141-148

Choi YS, Hwang IS, Kang TJ, Lim JR, Choe KR (2011) Oviposition characteristics of Ricania sp. (Homoptera: Ricaniidae), a new fruit pest. Kor J Appl Entomol 50: 367-372

Cuthbertson AGS, Blackburn LF, Northing P, Luo W, Cannon RJC, Walters KFA (2009) Leaf dipping as an environmental screening measure to test chemical efficacy against Bemisia tabaci on poinsettia plants. Int $\mathrm{J}$ Environ Sci Tech 6: 347-352

Gbolade AA, Oyedele AO, Sosan MB, Adwayin FB, Soyela OL (2000) Mosquito repellent activities of essential oils from two Nigerian Ocimum species. J Trop Med Plants 1: 146-148

Hyun HB, Shrestha S, Boo KH, Kim SM (2015) Evaluation of antioxidant potential of ethyl acetate fraction of Rosmarinus officinalis $\mathrm{L}$. and its major components. J Korean Soc Appl Biol Chem 58: 715-722

Isman MB (2000) Plant essential oils for pest and disease management. Crop Prot 19: 603-608

Kim DY, Kim SH, Ahn HM, Lim SR, Oh JS, Choi SG, Lee HJ, Auh JH, Choi HK (2015) Differentiation of highbush blueberry (Vaccinium corymbosum L.) fruit cultivars by GC-MS-based metabolic profiling. J Korean Soc Appl Biol Chem 58: 21-28

Lee HW, Lee HS (2015) Acaricidal potency of active constituent isolated from Mentha piperita and its structural analogs against pyroglyphid mites. J Korean Soc Appl Biol Chem 58: 597-602

Lee HW, Lee SG, Lee HS (2016) Active component isolated from Eugenia caryophyllata leaves and its structural analogues show insecticidal properties against Pochazia shantungensis. Appl Biol Chem 59: 1-6

Rahman MA, Kwon YJ, Suh SJ, Youn YN, Jo SH (2012) The genus Pochazia amyot and serville (Hemiptera:Ricaniidae) from Korea, with a newly recorded species. J Entomol 9: 239-247

Shen Q, Wang JY, Liu JD, Chen YF, Fan XH, Zhu YQ (2007) Bionomios and control of Ricania shantungensis. Chinese Bull Entomol 44: 116-119

$\mathrm{Xu}$ CQ, Liang AP, Jiang GM (2006) The genus Euricanla melichar (Hemiptera: Ricaniidae) from china. Raffles Bull Zool 54: 1-10 